\title{
ANALISIS KESULITAN SISWA KELAS V DALAM MENENTUKAN IDE POKOK PARAGRAF
}

\author{
ANALYSIS OF THE DIFFICULTIES OF CLASS V STUDENTS IN \\ DETERMINING THE MAIN IDEA OF THE PARAGRAPH
}

\author{
Eka Nur Oktafiani ${ }^{1}$, Dedy Irawan ${ }^{2}$ \\ Program Studi Pendidikan Guru Sekolah Dasar, Fakultas Keguruan dan Ilmu Pendidikan \\ Universitas Muhammadiyah Purwokerto, indonesia \\ e-mail: *1ekanuroktafiani10@gmail.com
}

\begin{abstract}
ABSTRAK
Kesulitan dalam belajar merupakan kesulitan yang selalu dialami oleh siswa dalam proses pembelajaran di Sekolah Dasar. Kesulitan dalam membuat paragraf seringkali menjadi masalah yang dialami oleh siswa setiap pembelajaran Bahasa Indonesia. Paragraf adalah salah satu materi yang ada di dalam pelajaran Bahasa Indonesia. Kesulitan yang dialami siswa dalam materi paragraf diantaranya adalah kesulitan dalam menentukan ide pokok. Kesulitan dalam menentukan ide pokok menjadi masalah cukup serius yang dialami oleh siswa di SD kelas V. Penelitian ini bertujuan untuk (1) Mengetahui kesulitan siswa dalam menentukan ide pokok paragraf di kelas V SD N 2 Dukuhwaluh (2) Mengetahui faktor yang menyebabkan siswa mengalami kesulitan dalam menentukan ide pokok paragraf. Penelitian ini adalah penelitian deksriptif kualitatif dengan metode studi kasus. Teknik pengumpulan data dengancara observasi, wawancara dan analisis dokumen. Teknik analisis data dari reduksi data, penyajian data dan verifikasi. Hasil penelitian menunjukan bahwa ditemukan dua siswa yang mengalami kesulitan dalam menentukan ide pokok di kelas V SD N 2 Dukuhwaluh. Kesulitan dalam menentukan letak ide pokok paragraf dan kesulitan dalam menulis ide pokok paragraf. Penelitian ini sangat berguna untuk mengetahui permasalahan yang terjadi setiap tahun di Sekolah Dasar kelas V.
\end{abstract}

Kata kunci: Kesulitan belajar, Bahasa Indonesia, Ide pokok

\begin{abstract}
Difficulties in learning are difficulties that are always experienced by students in the learning process in elementary schools. Difficulty in making paragraphs is often a problem experienced by students in every Indonesian language learning. Paragraphs are one of the materials in Indonesian lessons. The difficulties experienced by students in paragraph material include difficulties in determining the main idea. Difficulty in determining the main idea is a serious problem experienced by students in grade 5 elementary school. This study aims to (1) find out the difficulties of students in determining the main idea of a paragraph in class V SD N 2 Dukuhwaluh (2) find out the factors that cause students to have difficulty in determining the main idea of a paragraph. This research is a qualitative descriptive research with case study method. Data collection techniques by means of observation, interviews and document analysis. Data analysis techniques from data reduction, data presentation and verification. The results showed that there were two students who had difficulty in determining the main idea in class V SD N 2 Dukuhwaluh. Difficulty in determining the location of the main idea of the paragraph and difficulty in writing the main idea of the paragraph. This research is very useful to find out the problems that occur every year in the fifth grade elementary school..
\end{abstract}

Keywords: difficulty learning, indonesian, main idea 


\section{PENDAHULUAN}

Bahasa Indonesia diberikan di semua jenjang pendidikan formal, dari sekolah dasar hingga perguruan tinggi. Semua kurikulum dalam setiap jenjang pendidikan mewajibkan Bahasa Indonesia sebagai pelajaran pokok dengan tujuan memberikan nilai sastra dan menumbuhkan cinta tanah air siswa. Bahasa Indonesia merupakan mata pelajaran wajib yangdiajarkan pada setiap lembaga pendidikan di Indonesia [1]. Di sekolah dasar pembelajaran bahasa Indonesia ditujukkan untuk mengembangkan dan meningkatkan kemampuan siswa dalam berkomunikasi dengan baik, baik secara lisan maupun tulisan.

Bahasa Indonesia dalam implementasi kurikulum 2013, terintegrasi dengan muatan pelajaran lainnya tujuannya adalah agar siswa terampil dalam menggunakan bahasa [2]. Melalui pembelajaran bahasa Indonesia, siswa juga diharapkan mampu mengapresiasi hasil karya indonesia dengan baik. Hal ini karena siswa akan berhadapan dengan dunia sastra nantinya dan memiliki kehidupan yang tidak akan jauh dari nilai-nilai sastra. Cakuan pembelajaran bahasa Indonesia sesuai dengan Kurikulum 2013 pada jenjang SD/MI meliputi komponen kemampuan berbahasa dan bersastra yang meliputi 4 aspek yaitu mendengarkan, berbicara, membaca, menulis.

Pelajaran Bahasa Indonesia belum diterima dengan mudah oleh sebagian siswa. Kesulitan dalam mempelajari Bahasa Indonesia akan berpengaruh terhadap keterampilan berbahasa siswa seperti keterampilan menulis dan keterampilan membaca. Menulis yaitu salah satu dari empat keterampilan bahasa yang sangat penting untuk dipelajari karena menulis mempunyai beberapa elemen penting bagi siswa yaitu organisasi kalimat, ejaan, kosakata, tanda baca dan tata bahasa [3]. Syarat siswa dapat menulis dengan baik yaitu siswa harus menguasai beberapa tahapan keterampilan bahasa yang lainnya dahulu. Oleh sebab itu, kompetensi berbahasa siswa dapat tercapai dalam keterampilan menulis. Siswa dapat mempelajari banyak hal untuk dijadikan sebuah sumber tulisan Keterampilan membaca adalah keterampilan berbahasa dengan menggunakan konsentrasi tinggi untuk memahami suatu bacaan khususnya bacaan paragraf.

Kesulitan dalam pelajaran Bahasa Indonesia merupakan kesulitan yang dapat dialami oleh semua siswa. Hal ini karena kesulitan pelajaran Bahasa Indonesia bukan hanya kesulitan dalam ketrampilan berbahasa saja akan tetapi juga kesulitan dalam memahami konsep, prinsip, serta aplikasinya terhadap lingkungan sekitar. Kesulitan siswa ini bisa menjadi tantangan untuk guru dan orang tua karena dalam ketrampilan bahasa Indonesia, siswa tidak hanya mendapatkan pembelajaran di sekolah saja akan tetapi orang tua juga ikut serta dalam proses belajar anak di dalam rumah. Kesulitan siswa dalam bahasa Indonesia diantaranya adalah kesulitan dalam materi paragraf. Faktor yang menyebabkan siswa mengalami kesulitan dalam materi paragraf berasal dari faktor internal dan faktor eksternal. Faktor internal siswa adalah keadaan-keadaan yang muncul dari dalam diri siswa itu sendiri, sementara itu faktor eksternal siswa mencakup hal-hal atau keadaan yang datang dari luar diri siswa itu sendiri [4]. Selain itu, minat dan kemampuan membaca juga berpengaruh bagi siswa dalam teks bacaan yang disajikan [5]. Oleh sebab itu, halhal yang menjadi penyebab kesulitan dalam pelajaran bahasa Indonesia perlu segera diatasi, agar tidak mengganggu peroses pembelajaran padda muatan pelajaran yang lain.

Berdasarkan hasil observasi peneliti di SD N 2 Dukuhwaluh didapatkan hasil penelitian bahwa setiap tahunnya dikelas $\mathrm{V}$ terdapat 1 sampai 3 siswa yang mengalami kesulitan dalam menentukan ide pokok. Berdasarkan hasil observasi dan wawancara terhadap guru kelas $\mathrm{V}$ tahun 2021 terdapat 2 siswa yang mengalami kesulitan dalam menentukan ide pokok. Walaupun pembelajaran dilakukan secara daring di rumah siswa akan tetapi kesulitan siswa harus tetap diperhatikan dan dicari solusi yang tepat untuk mengatasi permasalahan tersebut. Dari hasil wawancara dapat diperoleh bahwa 2 siswa mengalami kesulitan dalam menentukan letak ide pokok bacaan paragraf dan sulit menulis ide pokok sesuai bacaan paragraf. hal tersebut disebabkan karena kurangnya pemahaman siswa tentang materi paragraf dan kurangnya konsentrasi siswa pada saat membaca paragraf. Siswa masih merasa sulit ketika mencari ide 
Jurnal Ilmiah KONTEKSTUAL, Volume.3, No.1, Agustus 2021, pp. 8-14

pokok dari sebuah bacaan paragraf karena tidak membaca bacaan paragraf dengan teliti dan tidak bisa membedakan ide pokok dan kata penjelas. Oleh sebab itu, peneliti tertarik untuk melakukan penelitian mengenai analisis kesulitan siswa dalam menentukan ide pokok di kelas V SD N 2 Dukuhwaluh. Penelitian ini diharapkan mampu memberikan pemahaman kepada pembaca mengenai kesulitan siswa dalam menentukan ide pokok dan faktor yang menyebabkan siswa mengalami kesulitan dalam menentukan ide pokok.

\section{METODE PENELITIAN}

Metode Penelitian yang digunakan dalam penelitian ini adalah metode kualitatif. Sementara itu, jenis penelitian yang digunakan dalam penelitian ini menggunakan jenis penelitian studi kasus. Tempat Penelitian dilaksanakan di SD Negeri 2 Dukuhwaluh Kecamatan Kembaran, Kabupaten Banyumas karena di SD Negeri 2 Dukuhwaluh permasalahan ini menjadi permasalahan yang terjadi setiap tahun dan permasalahan yang mencakup semua materi di pelajaran Bahasa Indonesia Penelitian ini dilakukan dari Februari sampai April 2021 dengan pelaksanaan penelitian sesuai protokol kesehatan yaitu menggunakan masker, menjaga jarak, dan mencuci tangan. Sumber data penelitian kualitatif adalah pihak-pihak yang menjadi sasaran penelitian yang dapat memberikan informasi pada penelitian ini. Sumber data dalam penelitian ini menggunakan data primer dan data sekunder. Data primer adalah data yang berasal dari individu maupun kelompok yang bisa diambil melalui teknik wawancara dan observasi. Data primer dalam penelitian ini adalah siswa kelas V dan Guru kelas V. Data sekunder adalah data yang berfungsi melengkapi data primer. Data sekunder yang digunakan dalam penelitian ini adalah data wawancara orang tua siswa. Pada penelitian ini, peneliti menggunakan teknik wawancara, observasi dan analisis dokumen. Wawancara akan dilakukan di rumah siswa dan observasi akan dilakukan dengan melihat proses pembelajaran siswa secara daring melalui aplikasi WhatsApp. Sedangkan untuk analisis dokumen peneliti akan menganalisis buku tema 6 siswa dan menganalisis hasil Ujian Tengah Semester (UTS) Bahasa Indonesia siswa.

\section{HASIL DAN PEMBAHASAN}

\section{Hasil Penelitian}

Berdasarkan hasil penelitian, peneliti dapat memaparkan hasil penelitian sesuai dengan tujuan penelitian yaitu mengetahui kesulitan yang dialami siswa pada menentukan ide pokok dan faktor yang menyebabkan siswa mengalami kesulitan dalam menentukan ide pokok. Adapun data dari hasil penelitian yang sudah dilakukan adalah sebagai berikut :

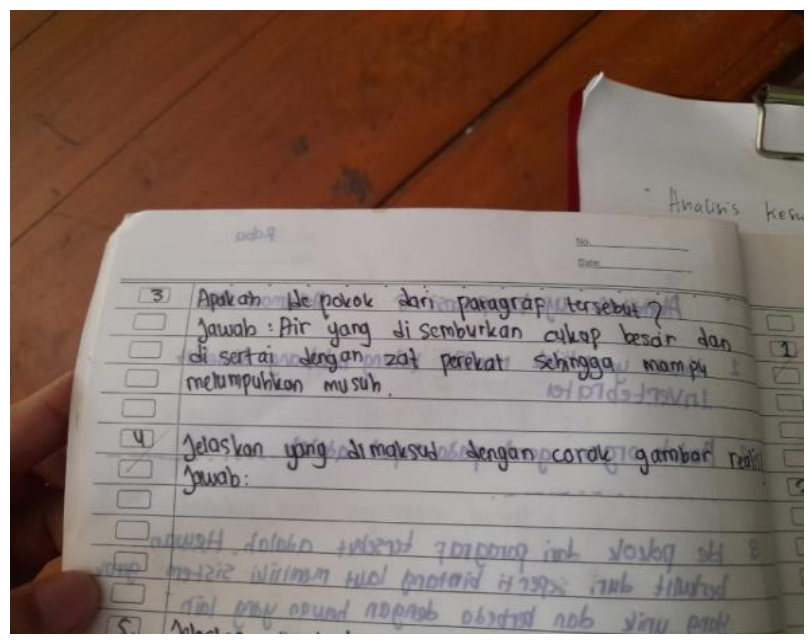

Gambar 1 Buku Tugas VI/PD 
Dari buku tugas VA/PD diatas dapat dilihat bahwa VA/PD masih belum tepat dalam menjawab soal menentukan ide pokok dari sebuah paragraf. Ide pokok adalah inti dari sebuah bacaan maupun suatu paragraf untuk mengetahui pokok atau inti bacaan tersebut. Dari jawaban soal tersebut VA/PD menjawab dengan kurang tepat karena VA/PD menulis jawaban dengan kalimat penjelas bukan ide pokok atau gagasan utamanya. Ciri-ciri yang paling menonjol dari ide pokok adalah biasanya terletak dikalimat utama. VA/PD masih belum tepat dalam menentukan ide pokok karena VA/PD tidak mengetahui pengertian dari ide pokok dan bagaimana cara menentukan atau menemukan ide pokok tersebut serta merasa sulit dalam memahami paragraf tersebut. Hal ini sejalan dengan penjelasan dari N/GK bahwa siswa yang mengalami kesulitan dalam materi paragraf kemungkinan akan mengalami kesulitan pada ide pokok dan cenderung malas dalam membaca sebuah bacaan, jadi siswa yang mengalami kesulitan dalam menentukan ide pokok berasal dari kesulitan memahami suatu bacaan paragraf.

Dari hasil penelitian yang dilakukan oleh peneliti juga menemukan bahwa terdapat satu siswa yang mengalami permasalahan yang sama seperti VA/PD.

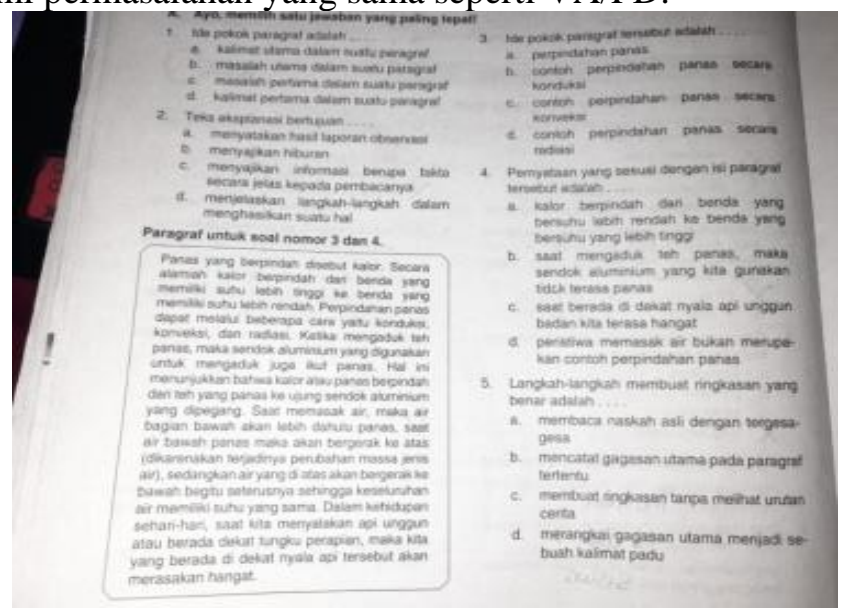

Gambar 2 Soal Uji Kompetensi tema 6 DI/PD

Dokumentasi diatas merupakan lembar soal uji kompetensi tema 6 subtema 2 dengan pertanyaan menentukan ide pokok dari sebuah bacaan dengan tema materi kalor. DI/PD harus menentukan jawaban dengan pilihan ganda dari A sampai D. Soal tersebut memiliki 1 paragraf dengan penjelasan mengenai kalor secara jelas. Dari hasil penelitian DI/PD menjawab soal tersebut dengan jawaban B. Berikut analisis dokumentasi lembar jawaban dari soal uji kompetensi tersebut:

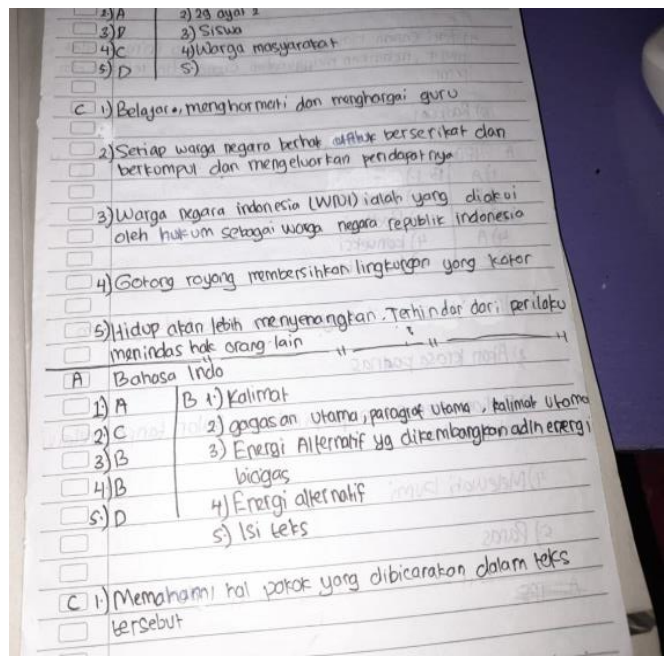

Gambar 3 Jawaban Uji Kompetensi Tema 6 DI/PD 
Dari dokumentasi diatas dapat dilihat bahwa jawaban DI/PD pada soal nomor 3 adalah B. Setelah peneliti analisis jawaban tersebut masih belum tepat karena jawaban yang benar adalah A. Hal ini dikarenakan pada soal nomor 3 isi bacaan dari paragraf tersebut adalah tentang perpindahan panas yaitu kalor dan pada kalimat selanjutnya menjelaskan tentang cara kerja perpindahan panas. Ide pokok bisa dilihat pada kalimat pertama dan pada paragraf tersebut ide pokoknya terletak pada kalimat utama di kalimat pertama yaitu perpindahan panas dan jawaban yang tepat adalah A.

Berdasarkan analisis dokumen dan penjelasan diatas dapat disimpulkan bahwa VA/PD dan DI/PD mengalami kesulitan dalam menentukan ide pokok karena mereka tidak memahami isi bacaan dan tidak mengerti letak ide pokok atau gagasan utama di setiap paragraf. Semestinya, setiap bacaan paragraf harus dipahami dengan baik dan benar agar bisa menjawab soal-saol yang berkaitan dengan paragraf tersebut seperti, menentukan ide pokok dan menentukan informasi penting pada bacaan paragraf tersebut.

Peneliti juga menemukan kesulitan siswa dalam menulis paragraf. Paragraf adalah kumpulan kalimat yang terbentuk menjadi suatu bacaan dengan minimal 5 kalimat disertai dengan kata penghubung dan awal kalimat yang menjorok ke dalam. Dua siswa yang mengalami kesulitan dalam menulis paragraf adalah siswa yang mengalami kesulitan dalam menulis pola paragraf, sulit menggunakan kata penghubung serta sulit dalam menggunakan Bahasa Indonesia yang baik dan benar atau sesuai EYD. Siswa selalu lupa jika menulis paragraf awal kalimat harus menjorok kedalam. Penggunaan transisi atau kata penghubung juga menjadi masalah siswa dalam menulis paragraf, contohnya adalah menggunakan kata penghubung (atau, seperti, oleh karena itu, sehingga).

Peneliti menemukan bahwa faktor yang sangat berpengaruh dalam kesulitan siswa menerima materi paragraf adalah faktor psikologis yaitu ketertarikan atau minat mempelajari Bahasa Indonesia. Siswa yang memiliki kesulitan dalam pembelajaran Bahasa Indonesia akan sulit menerima materi yang berkaitan dengan Bahasa Indonesia, padahal bahasa Indonesia merupakan pelajaran yang sangat membantu siswa meningkatkan keterampilan berbahasanya seperti keterampilan berbicara, mendengarkan, membaca serta menulis.

Faktor lain yang menyebabkan siswa mengalami kesulitan pada materi paragraf adalah faktor kondisi lingkungan yang dilihat dari kondisi lingkungan mengenai bahasa yang digunakan dalam berkomunikasi sehari-hari. SD Negeri 2 Dukuhwaluh terletak di kecamatan kembaran kabupaten banyumas. Selain menggunakan Bahasa Indonesia sebagai bahasa komunikasi, siswa juga menggunakan bahasa Jawa ngapak untuk berkomunikasi dengan teman sebayanya. Hal ini berpengaruh terhadap penggunaan Bahasa yang digunakan oleh siswa dalam menulis paragraf. Dua siswa tersebut mengalami kesulitan dalam menggunakan Bahasa Indonesia yang baik dan benar saat menulis sebuah kalimat. Hal ini terjadi karena kosakata Bahasa Indonesia yang dimilikinya sangat sedikit sehingga sulit mengembangkan kalimat.

\section{Pembahasan}

Dari penelitian yang sudah dilakukan oleh peneliti ditemukan bahwa terdapat 2 siswa yang mengalami kesulitan dalam menentukan ide pokok. Kesulitan tersebut dapat dilihat dari hasil kerja siswa dan lembar uji kompetensi siswa. Berdasarkan hasil penelitian, peneliti menemukan bahwa faktor yang sangat berpengaruh dalam kesulitan siswa menerima materi paragraf adalah faktor psikologis yaitu ketertarikan atau minat mempelajari Bahasa Indonesia. Siswa yang memiliki kesulitan dalam pembelajaran Bahasa Indonesia akan sulit menerima materi yang berkaitan dengan bahasa Indonesia, sehingga siswa menjadi lemah dalam bahasa Indonesia. Lemahnya bahasa Indonesia sebenarnya terjadi karena karena masih rendahnya seseorang mengehargai Bahasa Indonesia serta masih malas dalam membaca [6].

Hasil penelitian yang menunjukan bahwa siswa yang mengalami kesulitan dalam menentukan ide pokok menunjukkan tidak memahami dengan baik materi paragraf. dari hasil penelitian ini juga menunjukkan bahwa keterampilan berbahasa yang dimiliki siswa masih rendah, seeprti keterampilan membaca dan menulis. Hasil penelitian, selaras dengan penelitian 
terdahulu yang menunjukkan bahwa kesulitan yang dialami siswa dalam menentukan ide pokok yaitu, belum menguasainya materi ide pokok dan kesulitan saat menemukan kosa kata yang belum dipahami dan kesulitan ketika menentukan ide pokok dari kalimat atau paragraf yang banyak [7]. Faktor penyebabnya adalah faktor internal dan eksternal siswa. Faktor internal mencakup sulit berkonsentrasi saat pembelajaran, jenuh saat belajar, minat baca, motivasi belajar, kurang memahami materi. Faktor eksternal yaitu, metode mengajar dan media pembelajaran.

\section{SIMPULAN}

Berdasarkan hasil penelitian dapat dikemukakan bahwa kesulitan yang dialami siswa dalam Pembelajaran Bahasa Indonesia merupakan masalah yang penting dan harus segera di lakukan upaya untuk mengatasi permasalahan tersebut. Kesulitan dalam pelajaran Bahasa Indonesia sangat berpengaruh terhadap keterampilan berbahasa siswa sehingga hasil penelitian ini sangat bermanfaat untuk mengetahui kesulitan siswa dalam materi paragraf serta pembaca mengetahui faktor-faktor yang menyebabkan kesulitan siswa dalam materi paragraf sehingga perlu adanya upaya yang harus dilakukan untuk mengatasi permasalahan tersebutKesulitan yang dialami siswa pada materi paragraf adalah kesulitan dalam menentukan ide pokok (tidak mengetahui letak ide pokok atau gagasan utama disetiap bacaan paragaf). Sulit menemukan dan menentukan informasi atau hal-hal penting yang terdapat dalam suatu bacaan paragraf, serta sulit dalam menulis suatu paragraf (pola penulisan yang masih salah. Penggunaan huruf belum sesuai EYD. Tidak memperhatikan kata penghubung, masih salah dalam menggunakan Bahasa Indonesia dalam menulis sebuah cerita atau bacaan paragraf. Faktor yang menyebabkan siswa mengalami kesulitan dalam materi paragraf adalah kurang minatnya siswa pada pelajaran Bahasa Indonesia, mempunyai keyakinan bahwa Bahasa Indonesia sulit dipahami dan sulit untuk dipelajari, tidak adanya semangat belajar karena pandemi covid-19

\section{DAFTAR PUSTAKA}

[1] G. M. Johan and R. Rindawati, "Interferensi morfogis bahasa simeuleu dalam pembelajaran menulis karangan narasi pada siswa kelas V SD Negeri 10 Simeulue Tengah," Jurnal Metamorfosa, vol. 6, no. 1, pp. 27-39, 2018, [Online]. Available: https://ejournal.bbg.ac.id/metamorfosa/article/view/189.

[2] S. F. Anzar and M. Mardhatillah, "Analisis kesulitan belajar siswa pada pembelajaran bahasa Indonesia di kelas V SD Negeri 20 Meulaboh Kabupaten Aceh Barat tahun aajaran 2015/2016," Bina Gogik: JUrnal Ilmiah Pendidikan Guru Sekolah Dasar, vol. 4, no. 1 Maret 2017, pp. 53-64, 2017, [Online]. Available:

https://ejournal.stkipbbm.ac.id/index.php/pgsd/article/view/25.

[3] R. Purba, "Improving the achievement on writing narrative text through discussion starter story technique," Advances in Language and Literary Studies, vol. 9, no. 1, pp. 27-30, 2018, [Online]. Available:

http://www.journals.aiac.org.au/index.php/alls/article/view/4074.

[4] R. H. Hamonangan and S. Widyarto, "Pengaruh self regulated learning dan self control terhadap hasil belajar bahasa Indonesia," Jurnal Dimensi Pendidikan dan Pembelajaran, vol. 7, no. 1, pp. 5-10, 2019, [Online]. Available:

http://journal.umpo.ac.id/index.php/dimensi/index.

[5] P. Astuti, A. Mumpuni, and B. A. Pranoto, "Pengaruh Minat Dan Kemampuan Membaca Peserta Didik Dalam Memahami Teks Bacaan,” Jurnal KONTEKSTUAL, vol. 1, no. 1, pp. 26-32, 2019, [Online]. Available: http://jurnal.umus.ac.id/index.php/kontekstual/article/view/55.

[6] S. Widiyarto, "Pengaruh minat baca dan penguasaan kosakata terhadap keterampilan menulis eksposisi,” Pesona: Jurnal Kajian Bahasa dan Sastra, vol. 3, no. 1, pp. 74-80, 
2017, [Online]. Available: https://core.ac.uk/download/pdf/229583964.pdf.

[7] E. Kurniawati, A. Sutarjo, and D. Wardana, "Analisis kesulitan siswa kelas IV SD

Negeri Banjarsari 5 dalam menentukan ide pokok paragraf," Kalimaya, vol. 7, no. 2, pp. 1-13, 2019, [Online]. Available:

http://antologi.upi.edu/file/A_40_Ennok_Kurniawati_1507281.pdf. 